\title{
CONCEPTUAL MODEL FOR SME DIGITAL TRANSFORMATION DURING THE COVID-19 PANDEMIC TIME IN INDONESIA: R- DIGITAL TRANSFORMATION MODEL
}

\author{
Arianto Muditomo, Indra Wahyudi* \\ Business Management, School of Business, IPB \\ Jl. Raya Pajajaran, Bogor, West Java, 16151 \\ *E-mail: indrawahyudi@apps.ipb.ac.id
}

\begin{abstract}
Digital transformation is one that has been accelerated in response to the COVID-19 pandemic that has hit the world since the end of 2019. As a sector that has proven reliable in facing the SME crisis, it is encouraged to accelerate its digital transformation process due to the distance limitation policy imposed during the pandemic. This article aims to assess the importance of understanding the right digital transformation model for each SME, especially in taking advantage of the accelerated momentum due to the social restriction policies imposed during the COVID-19 pandemic, because choosing the right model will provide a better probability of successful transformation. This research is qualitative research through content analysis to produce a theoretical model construction of the digital transformation model for SMEs in Indonesia which we call the reasonable digital transformation model for SME (R-DT for SME). The conclusion obtained is that based on the mapping of the digital transformation of SMEs in Indonesia on the R-DT model, it can be concluded that: (1) The main trigger for DT UKM is the external driver, not many internal drivers have been found, especially during the COVID-19 pandemic. what is done is still reactive in nature and tends to only follow the steps of the transformation of other actors so as not to create a uniqueness of the said SMEs which will result in the loss of opportunities to have a competitive advantage over competitors; (2) In general, the implementers of DT UKM have set a strategic imperative for their decision to carry out digital transformation, but have not set a measurable milestones so that the digital transformation carried out cannot be measured the level of success; (3) DT which is done in general is to change some of the company's operations to digital, this shows the low digital maturity of SMEs in Indonesia today.
\end{abstract}

Keywords: COVID-19, Digital Transformation, SME

\section{INTRODUCTION}

Since the end of 2019 and continuing throughout 2020, the whole world has been busy with the incidence and impact of the COVID-19 pandemic. A new type of
COVID-19 or Corona Virus Diseases was first discovered in Wuhan City, Hubei Province, China. The outbreak of a respiratory disease called COVID-19 by the World Health Organization (WHO), was 
reported on December 31, 2019, and then WHO declared COVID-19 as a global health emergency of international concern on January 30, 2020 (Gallegos 2020). Furthermore, WHO declared COVID-19 a pandemic on March 11, 2020, because of its wide and rapid spread to all continents in the world dan globally, as of 7:11 pm CET, 22 January 2021, there have been 96,267,473 confirmed cases of COVID-19, including 2,082,745 deaths, reported to WHO.

The COVID-19 pandemic not only has an impact on health problems but the global economy has also been affected, including the economy in Indonesia. Many countries in the world implement control policies. These control policies cover contact tracing, isolation, quarantine, working from home, and large-scale social distancing. In Indonesia itself, this control policy has a profound impact on socioeconomic activities. COVID-19 has stopped economic activities in Indonesia because many companies have closed their businesses, resulting in a very high unemployment rate.

This article will further focus specifically on the impact of the COVID-19 pandemic on the SME sector. MSMEs as a pillar of the Indonesian economy have proven to be the strongest to survive during previous crisis conditions such as the 1998 crisis where when many large businesses and banks went bankrupt, SME exports increased $350 \%$ (Santia 2020) also feel the tremendous impact amid the COVID-19 pandemic. Based on data from the ministry of cooperatives and MSMEs, 90\% of UMKM activities are disrupted due to the COVID-19 pandemic (Kristianus 2020). The implementation of large-scale social restrictions has made the sales of SMEs decrease due to the prohibition of activities in public places, including work activities that must be done at home. The COVID-19 pandemic has greatly affected the sustainability activities of SMEs in Indonesia and other countries. The COVID19 pandemic resulted in reduced demand for MSME products, which affected the company's financial condition (cash flow), which in turn caused MSMEs to be unable to pay credit, interest, and even taxes (Santia 2020).

Many experts claim that increasing the productivity and performance of SMEs requires the role of digital technology (Papadopoulos, Baltas, and Balta 2020). Digital technology plays an important role in the performance of SMEs in this time of large-scale social restrictions. Most of the business and administrative processes must be done digitally. As a result, digitization in the SME business is not only carried out in the business process from the company to the customer but also in the process from the company to the employee. This makes SMEs and customers infrastructure ready for digital transformation. Data from the Ministry of Cooperatives and MSMEs, currently there are 64 million MSME players, and only around 8 million or around $13 \%$ are already connected to the digital world (D. Andriani 2020).

This article aims to assess the importance of understanding the right digital transformation model for each SME, especially in taking advantage of the accelerated momentum due to the social restriction policies imposed during the COVID-19 pandemic, because choosing the right model will provide a better probability of successful transformation. 
Academics are accustomed to using the term "digital transformation" as a term to express organizational change influenced by digital technology. Digital transformation causes changes driven by technological developments in both organizations and society. According to (Henry Lucas et al. 2013). These changes relate to adjustments to business processes, changes in the relationship between the company and employees and customers, and market conditions. Digital transformation and the resulting business model innovations have fundamentally changed consumer expectations and behavior, suppressed traditional firms, and disrupted many markets (Verhoef et al.
2019). Ongoing changes in customer needs and behavior are forcing companies and public administrations to take the lead in digital transformation (Nachit and Belhcen 2020). All sectors require change and digital transformation is a process that many organizations or companies do.

Furthermore, the literature review in this article is carried out to identify research questions that are then relevant to reviews related to the main theme, namely digital transformation (DT) in Small and Medium Enterprises (SMEs) in Indonesia. Flow model adapted from (Verhoef et al. 2019) can carefully construct a clear DT flow model as shown in Figure 1 below.

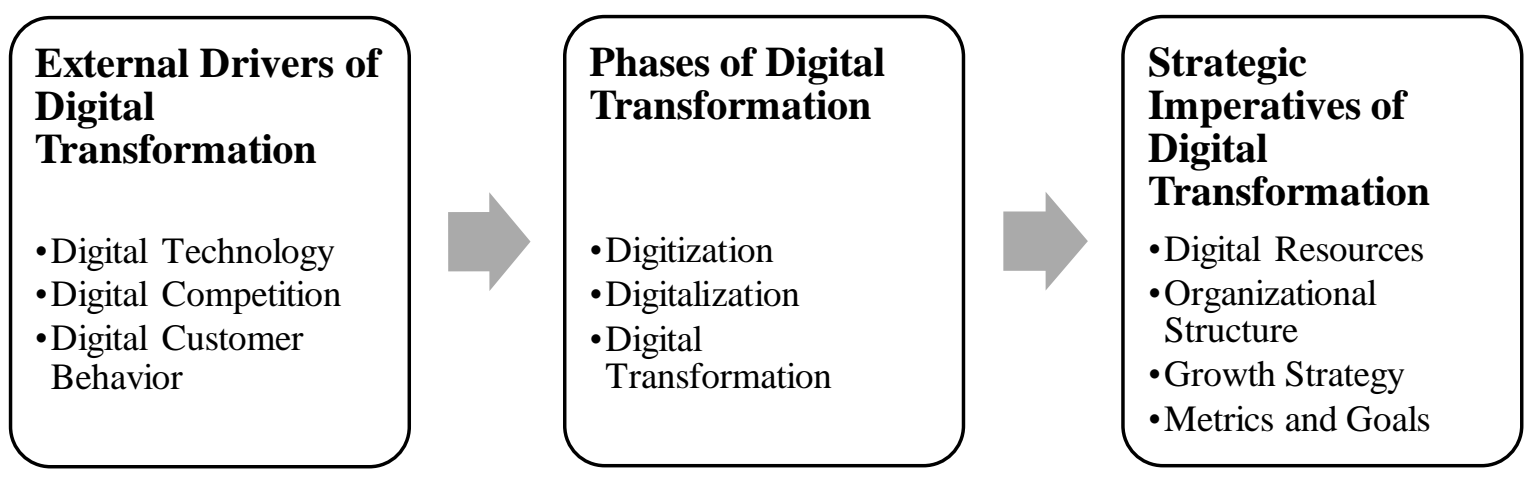

Figure 1. DT Flow Model (Verhoef et al. 2019)

Through the DT flow model above, the research questions for writing this article are arranged systematically as follows, namely First there is a plausible reason why Indonesian SMEs do DT during the COVID-19 pandemic, Second is a plausible explanation of the existence of the current and/or existing DT phase. was carried out by Indonesian SMEs during the COVID-19 pandemic, and Third is a plausible explanation of the strategic imperative DT that has been and/or should be carried out by Indonesian SMEs during the COVID-19 pandemic period.

\section{Reasons for UKM Doing DT}

SME entrepreneurs assess how the needs arising from COVID-19 because a business crisis can affect their business. Several indicators can be used to evaluate its reactive capacity and understand the impact of digital change whether it can reduce the negative impact of the COVID19 crisis. After conducting external and internal analysis, SMEs must determine 
their business models. Digital transformation not only introduces new technology to existing activities, but also the process of redesigning all business models (Fitriasari 2020).

The distance limitation policy imposed by the government in almost all countries has changed people's behavior in all aspects of their social life. This change of course affects customer expectations and behavior to be more inclined to use digital interaction devices (digital behavior). This change in behavior towards digital is one of the triggers for the acceleration of digital transformation, in addition to the very rapid development of digital technology and intense competition (Verhoef et al. 2019).

\section{The existence of the DT Phase conducted by UKM}

In general, the DT phase consists of the digitization phase, the digitalization phase, and the digital transformation phase, Digitization is an action to convert analog information into digital information, digitalization explains how IT or digital technology can be used to change existing business processes, while digital transformation is a phenomenon in across companies with broad organizational implications where the core business model of the company can change through the use of digital technology (Verhoef et al. 2019). In their article (Zaoui and Souissi 2020) categorizing the next phase of DT for mapping needs, we selected several categories in the phase, namely the defining strategy phase and milestones, the strategic imperative targeting phase, the information technology integration phase, and the full implementation phase.

\section{DT Strategic Imperative Performed by UKM}

DT is causing profound, technologydriven change to organizations and society. The fundamental characteristics of DT are the complex innovation of digital technology in all societal systems, changes in market fundamentals, volatility, reshaping of boundaries, as well as fundamental changes in business models (Kossowski et al., 2020).

The follow-up to the existence of the DT phase will have strategic imperative consequences for SMEs. Quoted from (Priyono, Moin, and Putri 2020), it was found that the choice of SME strategy in conducting DT during the COVID-19 pandemic can be classified into 3 degrees of digital strategy, namely First, SMEs with a high level of digital maturity who answer challenges by accelerating the transition to digital companies; Second, SMEs experiencing liquidity problems and low levels of digital maturity decide to only digitize the sales function; and Third, SMEs that have very limited digital literacy but are supported by high social capital will solve the challenge by finding partners who have excellent digital capabilities.

\section{RESEARCH METHODS}

The analysis is carried out in the form of a documentary review through content analysis which consists of scanning the literature in detail on the subject to identify common threads and understand the thoughts around them. This research is qualitative and aims to produce a theoretical model construction. The documentary review methodology provided this qualitative data for the study. Current techniques and methods that have been documented by the author in literature, 
journals, press papers, and other public sources have been surveyed and common threads identified and crystallized (Kode, Ford, and Sutherland 2003).

Qualitative method choose because it is the most suitable approach to explore and understand phenomena and answer questions that arise. We selected an exploratory case study design suitable for research in new areas where "little is known and literature is scarce" and therefore used to generate new research questions that can be explored further in future research (Nachit and Belhcen 2020).

Since the writing of this article was carried out only through the analysis of the literature construct, the findings of this study have not been empirically validated. The bias of research results may occur due to the limitations of sampling techniques and literature sources. Furthermore, to ensure the novelty of the construct result model, the data for selected content analysis are documents, articles, and/or other scientific works published throughout 2020, and previous publications are excluded for relevant theoretical citations.

\section{ANALYSIS AND DISCUSSION}

When reviewing the literature defining digital transformation, definitions vary depending on perspective and perception. There are many differences of opinion among researchers about how digital transformation should be supported (Zaoui and Souissi 2020). Based on a critical review of previous research literature, we propose a conceptual model of DT for SMEs that can be adapted by Indonesian SMEs which we call a reasonable digital transformation model for SMEs (reasonable digital transformation model for SMEs/R-DT model for SME) as shown in Figure The following 2.

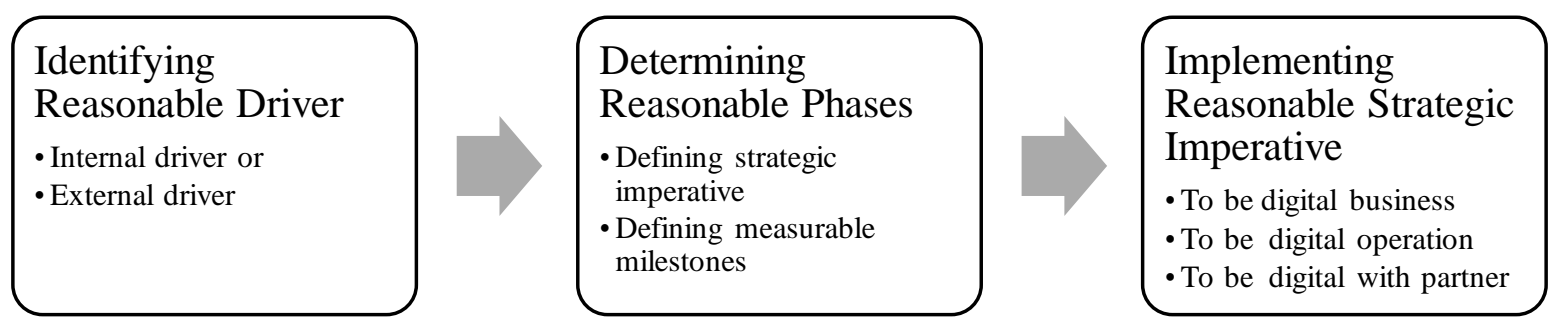

Figure 2. Reasonable Digital Transformation Model for SMEs / R-DT Model for SME

The R-DT model is a simplification of the flow model (Verhoef et al. 2019) to facilitate its implementation in SMEs according to digital maturity literacy and liquidity capabilities (Priyono, Moin, and Putri 2020). Driver identification is carried out at the initial step of the model to ensure the level of urgency of implementation, for example, the internal driver certainly has a relatively low urgency compared to the trigger for a pandemic condition (external driver) or at one time the internal driver in the form of operational digitization efforts can have a higher urgency with efficiency considerations when compared to external drivers in the form of changes in technology trends. The translation phase at the next stage is also important to ensure that the objectives of DT have been set complete with clear achievement measures and finally the management's decision to choose a strategic imperatives related to the outcome of the implementation of DT is to 
change the company's business model to be fully digital,

Furthermore, we use the R-DT model to review the top 60 by ranking scientific papers available to read in full online articles about DT in SMEs in Indonesia published throughout 2020. Scientific paper articles for this review need are searched using the Harzing's Publish or Perish application. from the Google Scholar source for the 2020-2021 search year range.

Table 1. R1-Reasonable Driver Mapping

\section{R1-Reasonable Driver}

\begin{tabular}{ll} 
Internal Driver & External Driver \\
\hline (Safitri and Vebriani 2020), & (Ardiani and Putra \\
(Zahiroh 2020), (R Taqiyya & 2020),(Suhardi et al. n.d.), \\
and Riyanto 2020), (Lita and & (Sadiyah and Candra \\
Surya 2020), (Pramawati, & 2020),(Purbasari, Muttaqin, \\
Putri, and ... 2020), & and Sari 2020) (Komalasari \\
(Rahatmawati, Istanto, and & et al. 2020), (Farizki et al. \\
& 2020), (Rizal et al. 2020), \\
& (Priyatna, Prastowo, and \\
& Syuderajat 2020), (Wibowo \\
& et al. 2020), (C. Andriani \\
& and Fitria 2020), (Kennedy, \\
& Tampubolon, and ... 2020), \\
& (Sasongko et al. 2020), \\
& (Sudaryana et al. \\
& 2020),(Krisnahadi 2020) \\
& (Lestari and Saifuddin \\
& 2020), (Redjeki and Affandi \\
& 2021)(Sukma, Hermina, and \\
& Novan 2020) (Santoso et al. \\
& 2020) \\
& \\
&
\end{tabular}

Based on a search of 60 journals obtained from Harzing's Publish or Perish application from Google Scholar sources for the search year span of 2020-2021, 20 journals can be classified as internal drivers and external drivers. Forty other journals are not included in the classification because they are training journals and general DT articles.

We categorize 7 journals into internal drivers which state that there are several SMEs that have been studied for digital transformation in the company because of the need for companies to improve company performance. There are thirteen classifications for external drivers which state that there are external measures that increase the motivation of MSMEs to improve performance with digital transformation. The existence of the Covid 19 pandemic is a major element of digital transformation through external elements From the analysis of previous research content regarding the reasons for doing DT UKM in Indonesia as shown in Table 1 above, it was found that during the pandemic period most of the reasons came from external drivers, while other articles 
for example(Purbasari, Muttaqin, and Sari 2020) only provides a qualitative review of the internal reasons for the driver. The implication of the reason why the DT UKM originated from the external driver resulted in the lack of DT variants in SMEs in Indonesia.

Table 2. R2-Reasonable Phases Mapping

\begin{tabular}{llll}
\hline & Not yet defined & Strategic Imperatives & $\begin{array}{l}\text { Measurable } \\
\text { Milestones }\end{array}$ \\
\cline { 2 - 4 } R2-Reasonable & (Allivia & (Hartanti and Oktiyani & (Rahmah Taqiyya and \\
Phases & 2020)(Muzdalifah, & 2020; Purbasari, & Riyanto 2020)(Sukma, \\
& Novie, and & Muttaqin, and Sari & Hermina, and Novan \\
& Zaqiyah 2020) & 2020)(Komalasari et & 2020) (Krisnahadi \\
& al. 2020)(Rahmah & 2020) \\
& Taqiyya and Riyanto & \\
& 2020)(Nurhavina & \\
& 2020)(Saragih 2020) & \\
&
\end{tabular}

In line with the results of the mapping of reasons for doing DT, most of which come from external drivers, as the results of the analysis of the content of the DT phase in SMEs are reactive and follow the market, namely finding uniformity of strategic imperatives to utilize digital marketing only without setting measurable milestones against the strategic imperatives chosen. Measurable milestones are found only in the article (Krisnahadi 2020; Rahmah Taqiyya and Riyanto 2020).

Table 3. R3-Reasonable Strategic Imperatives Implementation Mapping

\begin{tabular}{|c|c|c|c|c|}
\hline & $\begin{array}{l}\text { Not yet } \\
\text { defined }\end{array}$ & $\begin{array}{l}\text { To be Digital } \\
\text { Business }\end{array}$ & $\begin{array}{l}\text { To be Digital } \\
\text { Operation }\end{array}$ & $\begin{array}{l}\text { To be Digital } \\
\text { with Partner }\end{array}$ \\
\hline $\begin{array}{l}\text { R2-Reasonable } \\
\text { Phases }\end{array}$ & $\begin{array}{l}\text { (Muzdalifah, } \\
\text { Novie, and } \\
\text { Zaqiyah 2020) }\end{array}$ & $\begin{array}{l}\text { (Purbasari, } \\
\text { Muttaqin, and } \\
\text { Sari } \\
\text { 2020)(Nurhavina } \\
\text { 2020) }\end{array}$ & $\begin{array}{l}\text { (Hartanti and } \\
\text { Oktiyani } \\
\text { 2020)(Allivia } \\
\text { 2020)(Komalasari } \\
\text { et al. } \\
\text { 2020)(Sukma, } \\
\text { Hermina, and } \\
\text { Novan 2020) } \\
\text { (Krisnahadi } \\
\text { 2020)(Saragih } \\
\text { 2020) }\end{array}$ & $\begin{array}{l}\text { (Rahmah } \\
\text { Taqiyya and } \\
\text { Riyanto 2020) }\end{array}$ \\
\hline
\end{tabular}

Furthermore, the results of content analysis on the implementation of DT in SMEs in Indonesia, most SMEs in Indonesia implement DT in the 'to be digital operation' area. An explanation of this has been presented(Priyono, Moin, and Putri 2020) with the care that SMEs experiencing liquidity problems and low levels of digital 
maturity decide to only partially digitize their business functions.

\section{CONCLUSION}

Based on the analysis and discussion above, we conclude that based on the mapping of the digital transformation of SMEs in Indonesia on the R-DT model we have developed, it can be concluded that: (1) The main trigger of DT UKM is external driver, not many internal drivers have been found on DT UKM especially during the COVID-19 pandemic, the transformation carried out was still reactive in nature and tended to only follow the steps of the transformation of other actors so that it did not create a uniqueness of the said SMEs which resulted in the release of opportunities to have competitive advantages against competitors; (2) In general, the implementers of DT UKM have set a strategic imperative for their decision to carry out digital transformation, but have not set a measurable milestones so that the digital transformation carried out cannot be measured the level of success;

Based on the above conclusions, we can provide recommendations to researchers/academics, SMEs in Indonesia, digital service platform providers, and the government as follows. Researchers/ academics can use the R-DT model to carry out further research to evaluate the model for improvement and/or provide a flow model that can describe decision-making steps in determining strategic imperatives and measurable DT milestones. SMEs can use the R-DT model to guide the choice of strategies for implementing DT comprehensively and measurably. Digital service platform providers can use the RDT model to identify opportunities for providing digital service platforms for SMEs.

\section{REFERENCES}

Allivia, S T. 2020. "Pengaruh Transformasi Digital Terhadap Strategi Komunikasi Pemasaran UMKM." Studi Pustaka. http://kpm.ipb.ac.id/karyailmiah/index. php/studipustaka/article/view/8304.

Andriani, C, and Y Fitria. 2020. "PKM PENGEMBANGAN KAMPUNG ENTREPRENEUR BERBASIS DIGITAL MARKETING SEBAGAI MEDIA PROMOSI BAGI PELAKU UMKM DI KELURAHAN PASIE ...." Journal of Community Service.

Andriani, Dewi. 2020. “UMKM Didorong Adaptasi Di Masa Pandemi, Go Digital!" Bisnis.com. https://ekonomi. bisnis.com/read/20200 908/12/1288568/umkm-didorongadaptasi-di-masa-pandemi-go-digital (January 23, 2021).

Ardiani, W, and R Putra. 2020. "Pelatihan Berbasis Daring Dalam Penguatan Pemasaran Digital UKM Kota Medan.” Jurnal Abdidas.

Farizki, F I, R Salamah, T S R Mutiah, and ... 2020. "PENYULUHAN UMKM DI ERA NEW NORMAL DENGAN MEMPRIORITASKAN EKONOMI DIGITAL MARKETING." SELAPARANG ....

Fitriasari, Fika. 2020. "How Do Small and Medium Enterprise (SME) Survive The COVID-19 Outbreak?" Jurnal Inovasi Ekonomi 5(02): 53-62.

Gallegos, Alicia. 2020. "WHO Declares Public Health Emergency for Novel Coronavirus | CHEST Physician." Chest Physician. https://www.mdedge.com/chestphysici an/article/216449/coronavirus- 
updates/who-declares-public-healthemergency-

novel?channel $=284 \&$ sso $=$ true $($ January 23, 2021).

Hartanti, Hartanti, and Rina Oktiyani. 2020.

"Pengembangan Strategi Pemasaran

Ayam Barokah Melalui Digital

Marketing." Widya Cipta: Jurnal

Sekretari dan Manajemen 4(2): 183-

90.

https://ejournal.bsi.ac.id/ejurnal/index. php/widyacipta/article/view/8791.

Henry Lucas et al. 2013. "Impactful

Research on Transformational

Information Technology: An

Opportunity to Inform New

Audiences." MIS Quarterly 37(2):

371-82.

Kennedy, P S J, E Tampubolon, and ... 2020. "Simulasi Digital Marketing Kepada Peserta Webinar Di Jakarta Untuk Meningkatkan Ekonomi Keluarga." IKRA-ITH ....

Kode, G. V.M., J. C. Ford, and M. M.

Sutherland. 2003. "A Conceptual Model for Evaluation of Synergies in Mergers and Acquisitions: A Critical Review of The Literature." South African Journal of Business Management 34(1): 27-38.

Komalasari, Yeyen, Eka Putri Suryantari,

Ni Putu, and Dyah Krismawintari. 2020. "Strategi Digital Marketing Bagi Ukm Menghadapi Badai Pandemi Covid-19." Seminar Nasional ... (November): 79-82.

https://jurnal.undhirabali.ac.id/index.p hp/SINAPTEK/article/download/1212/ 1063.

Kossowski, Julia, Annika Lenz, Erich Heumüller, and Sebastian Richter. 2020. "Digital Fitness-The Goal of Digital Transformation." In $U K$ Academy for Information Systems
Conference Proceedings 2020., https://aisel.aisnet.org/ukais2020.

Krisnahadi, T. 2020. "Implikasi Covid Dengan Pemanfaatan Digital Marketing Terhadap Pendapatan Pelaku Usaha Kuliner Disekitar Obyek Wisata Pantai ...." Jurnal Ilmiah Mandala Education 4(4). http://ejournal.mandalanursa.org/index .php/JIME/article/view/1383.

Kristianus, Arnoldus. 2020. “Kemenkop UKM: 90\% UMKM Terdampak Pandemi Covid-19." Investor Daily Indonesia.

https://investor.id/business/kemenkopukm-90-umkm-terdampak-pandemicovid19 (January 23, 2021).

Lestari, P, and M Saifuddin. 2020. "IMPLEMENTASI STRATEGI PROMOSI PRODUK DALAM PROSES KEPUTUSAN PEMBELIAN MELALUI DIGITAL MARKETING SAAT PANDEMI COVID'19." Manova (Jurnal Manajemen dan ....

Lita, R P, and S Surya. 2020. "Pengembangan Motif Berbasis Digital Pada Usaha Tenun Kubang H. Ridwan By Di Kabupaten Lima Puluh Kota." Community Engagement and Emergence ....

Muzdalifah, Laily, Muhafidhah Novie, and Shofiyatus Zaqiyah. 2020. "Pemberdayaan Pelaku UMKM Menuju UMKM Go-Digital Di Era Pandemi Covid 19 Dan Era New Normal Bagi Pelaku UMKM Sidoarjo." Seminar Nasional Sistem ...: 2200-2208. https://www.jurnalfti.unmer.ac.id/inde x.php/senasif/article/view/296.

Nachit, Hicham, and Lhacen Belhcen. 2020. "Digital Transformation in Times of COVID-19 Pandemic: The 
Case of Morocco." SSRN Electronic Journal (1).

Nurhavina, D. 2020. "Empowerment of Digital Based Msmes In Communities in The New Normal Era." International Journal of Innovation Review. https://ijireview.com/ijir/article/view/1 4.

Papadopoulos, Thanos, Konstantinos N. Baltas, and Maria Elisavet Balta. 2020. "The Use of Digital Technologies by Small and Medium Enterprises during COVID-19: Implications for Theory and Practice." International Journal of Information Management 55(June): 102192. https://doi.org/10.1016/j.ijinfomgt.202 0.102192 .

Pramawati, IDAT, K M D Putri, and ... 2020. "Implementasi Digital Marketing Pada UMKM Di Kabupaten Klungkung Dalam Meningkatkan Profit.” Jurnal Pendidikan ....

Priyatna, C C, FXAA Prastowo, and F Syuderajat. 2020. "DIGITAL MARKETING UNTUK USAHA MIKRO KECIL MENENGAH (Studi Kasus Pada Coffeestrip Bandung).” Dharmakarya.

http://jurnal.unpad.ac.id/dharmakarya/ article/view/29478/0.

Priyono, Anjar, Abdul Moin, and Vera Nur Aini Oktaviani Putri. 2020.

"Identifying Digital Transformation Paths In The Business Model of SMEs During The Covid-19 Pandemic." Journal of Open Innovation: Technology, Market, and Complexity 6(4): 1-22.

Purbasari, R, Z Muttaqin, and D S Sari. 2020. "Digital Entrepreneurship in Pandemic Covid 19 Era: The Digital Entrepreneurial Ecosystem
Framework." buscompress.com. http://buscompress.com/uploads/3/4/9/ 8/34980536/riber_10-s1_12_u20071_114-135.pdf.

Rahatmawati, I, Y Istanto, and ... 2020. "Skill Empowerment for Crafts SMEs Managers in Facing Digital Marketing Demands (Case Study in Keparakan, Yogyakarta, Indonesia)." Proceeding of LPPM ....

Redjeki, F, and A Affandi. 2021. "Utilization of Digital Marketing for MSME Players as Value Creation for Customers during the COVID-19 Pandemic." International Journal of Science and ....

Rizal, M, A Aslinda, M J Firman, and ... 2020. "Pemanfaatan Digital Marketing Bagi Pelaku UMKM Di Kelurahan Malakaji Kabupaten Gowa." Seminar Nasional ....

Sadiyah, H, and I D Candra. 2020. "Managing Social Innovation In Crowdfunding Digital Platform." Airlangga Journal of Innovation ....

Safitri, H, and V Vebriani. 2020. "Pelatihan Pemasaran Digital Pada UKM Cita Rasa Kecamatan Rasau Jaya Kabupaten Kubu Raya.” BULETIN AL-RIBAATH.

Santia, Tira. 2020. "Banyak UMKM Indonesia Akan Bangkrut Di Desember 2020? - Bisnis Liputan6.Com." Liputan 6. https://www.liputan6.com/bisnis/read/ 4277806/banyak-umkm-indonesiaakan-bangkrut-di-desember-2020 (January 23, 2021).

Santoso, A, S Y Widowati, E Kurniawati, and ... 2020. "PEMASARAN ONLINE BAGI UKM MENUJU KESUKSESAN USAHA DI ERA DIGITAL." Jurnal Graha .... 
Saragih, M G. 2020. "Perkembangan

Digital Marketing Di Masa Pandemi Covid-19." Merdeka Kreatif di Era Pandemi Covid-19: Suatu .... https://books.google.com/books?hl=en $\& \mathrm{lr}=\& \mathrm{id}=\mathrm{Nxv5DwAAQBAJ} \& \mathrm{i}=\mathrm{fnd}$ $\& p g=\mathrm{PA} 85 \& \mathrm{dq}=\mathrm{dampak}+$ pandemi $+\mathrm{co}$ vid19+terhadap+pemasaran \&ots $=\mathrm{GKo}$ vyhYEO8\&sig=AaaintCLmyvFW0SZ cQbfF4pdn2Q.

Sasongko, D, I R Putri, V N Alfiani, and ... 2020. "Digital Marketing Sebagai Strategi Pemasaran UMKM Makaroni Bajak Laut Kabupaten Temanggung." Jurnal Ilmiah ....

Sudaryana, Y, S Sarwani, H Subur, and ... 2020. “... TEKNIS DIGITAL MARKETING SEBAGAI UPAYA DALAM MENINGKATKAN PENJUALAN IKM/UMKM DI KABUPATEN TANGERANG DI TENGAH PANDEMI COVID ...." Abdi Laksana: Jurnal ....

Suhardi, A R, V S Marinda, T Rohendra, and ... "PELATIHAN DIGITAL MARKETING PADA UMKM BINAAN KADIN JAWA BARAT DALAM MENGHADAPI ERA NEW NORMAL.” Jurnal Pengabdian ....

Sukma, A, N Hermina, and D Novan. 2020. "PENGARUH PRODUK, DISTRIBUSI DAN DIGITAL MARKETING TERHADAP MINAT BELI PRODUK UMKM BINAAN KADIN JABAR PADA SITUASI COVID-19." MANNERS.
Taqiyya, R, and S Riyanto. 2020. “... Pemanfaatan Media Sosial Facebook Dan Whatsapp Untuk Memperluas Jaringan Pemasaran Digital Benih Sayuran Oleh Wafipreneur Di Masa Pandemi Covid-19." Syntax Idea.

Taqiyya, Rahmah, and Sugeng Riyanto. 2020. "Strategi Pemanfaatan Media Sosial Facebook Dan Whatsapp Untuk Memperluas Jaringan Pemasaran Digital Benih Sayuran Oleh Wafipreneur Di Masa Pandemi Covid19." Syntax Idea 2(10): 813-26.

Verhoef, Peter C. et al. 2019. "Digital Transformation: A Multidisciplinary Reflection and Research Agenda." Journal of Business Research 122(July 2018): 889-901.

Wibowo, N M, K Karsam, Y Widiastuti, and ... 2020. "Penciptaan Keunggulan Bersaing Ukm Batik Melalui Penerapan Teknologi Pengering Batik Dan Digital Marketing." ... dan Corporate Social ....

Zahiroh, M Y. 2020. "Cybersecurity Awareness and Digital Skills on Readiness For Change in Digital Banking." Li Falah: Jurnal Studi Ekonomi dan Bisnis ....

Zaoui, Fadwa, and Nissrine Souissi. 2020. "Roadmap for Digital Transformation: A Literature Review." In Procedia Computer Science, Elsevier B.V., 621-28. https://doi.org/10.1016/j.procs.2020.07 .090 . 
Business and Entrepreneurship Incubator Center Universitas Muhammadiyah Jakarta

Baskara : Journal of Business and Entrepreneurship

Volume 3 No. 1 October 2020 